\title{
Democratic Government, Corruption Control, and Economic Development: Evidence from Nigeria with Cointegration Approach
}

\author{
Temitope Abraham Ajayi, PhD \\ Department of Economics, Strathclyde Business School, University of Strathclyde, Glasgow, United Kingdom \\ Email: temitope.ajayi@strath.ac.uk
}

\begin{abstract}
Nigeria returned to a democratic government in 1999. Evidence in the literature shows that democracy promotes economic development. In the recent past, the democratic trajectory of Nigeria has led to empirical debates about the democratization process of the developing states in particular, which is prone to multifaceted challenges. This study examines the impact of democratic government on Nigerian economic development using the VAR autoregressive approach. Our empirical work suggests that democracy has a long-run relationship with the economic development of Nigeria. Against our a priori expectations and established positions in some segments of the literature, this study identifies a negative impact of democracy on the economic development of Nigeria within our study period. On the other hand, the quality of the rule of law positively impacts economic development in Nigeria. Furthermore, the study finds a positive impact of corruption control in Nigeria with economic development, although observable evidence shows that the Nigerian government's anti-corruption institution is weak. This research paper recommends institutional reforms for the democratization process of Nigeria to fully harness one of the most significant dividends of democracy-economic development.
\end{abstract}

Keywords: Nigeria, Democracy, Development, Corruption, Cointegration.

DOI: $10.7176 / \mathrm{EJBM} / 13-15-01$

Publication date:August $31^{\text {st }} 2021$

\section{Introduction}

The presumption that democratic government better redistributes national income among the population has become one of the leading discussions among economic theorists, political thinkers, and perhaps the laymen in the 21 st century. Democracy has its origins in the western culture of governance, and democratic states are arguably the most exportable government systems in the modern world to the other parts of the world. Although democracy probably has shortcomings, the likelihood exists that an average form of democratic government is better than an autocratic regime. However, the democratic credentials of many of the developing countries that have recently embraced democracy after some prolonged periods of military dictatorship have come under empirical scrutiny in the literature. The investigation of such democratic institutions arose given the perceived differences in the operations and implementations of the developing states' democratisation process and the first world countries. The Nigerian economy is one of the reference points.

Some known dividends of democracy are the rule of law, promotion of an egalitarian society, equitable redistribution of income, economic growth, improvement in the healthcare system, advancement in economic planning, and adequate welfare provision for the population through a drastic reduction in poverty rates. By extension, evidence exists in the literature that democracy promotes economic development (Acemoglu et al. 2019; Lake and Baum, 2001; Olson, 1993; Pel, 1999; Ross, 2001, 2006). A critical observation of the Nigerian economy shows that many of the above-listed democratic ideals might not have been realized, or perhaps fully realized, within the last two decades. If so, does democracy offer the required solution to socio-economic challenges in a country like Nigeria? One of the political assumptions in Nigeria within the last decade is people's tendency to equate Nigeria's democratic experience as parallel to the military regime. The justification for such an assumption is based on the probable near- absence of Nigeria's basic dividend of democracy.

Further, there appears to be a growing frustration of the Nigerian population about the uncertain future of democracy. For instance, Nigeria is one of the poorest countries in the world. The unemployment rate in Nigeria has continued to grow. Despite Nigeria being a democratic state, the economic policy direction of Nigeria's state has remained a blur, and decaying infrastructure - detrimental to productivity, has continued to expand. The aggregate of these challenges listed above has led to the population's mistrust in the democratisation process.

Given such a contradiction, it has become imperative to examine the intersection between democracy and economic development in Nigeria. Because of the assumption that democratic states better provide rapid welfare and economic growth for the population, unlike the military regime, some scholars have conducted scholarly works on the impacts of democracy in Nigeria, immediately after Nigeria returned to a democratic government in 1999 like Jamo (2009, 2013), Ajayi, and Ojo (2014). We observe that such a hasty or short-run empirical investigation of democracy and economic growth in Nigeria could be flawed, given the likelihood that the 
implications of democratic government in Nigeria might not be instantaneous. Evidence in the literature shows that the scholarly work of Awojobi et al. (2014) is the only known empirical essay on the long-run impact of democracy and economic development in Nigeria to the best of our knowledge. However, the conclusions in Awojobi et al. (2014) are defective from a methodological standpoint. They did not carry out any empirical econometric work to strengthen their observations and findings of democracy and economic development. Substantial evidence in the literature shows that measuring democracy in a quantifiable way is crucial to drawing valid inferences. Several metrics of democracy exist in the literature. Our study overcomes that shortcoming by introducing quantitative democracy measurements to validate our results and findings on the impact of democracy on economic development.

As a follow-up to this, economic literature underscored that the time lag between policy formulation, policy implementation, and policy effects is critical in drawing valid conclusions about the observed effects of one variable on the other. Interestingly, 2019 marked twenty years of a democratic government in Nigeria, in the short-run and perhaps long-run context. We observe that the timing is right for determining the impacts of democratic government on Nigeria's economic development. That is the key motivation for this study: to unravel the effects of democracy on economic development in Nigeria after twenty years of uninterrupted democracy-a first in Nigerian history. Therefore, this study's novelty concerns an assessment of the implications of democracy on Nigeria's economic development with time-series data within the first twenty years of Nigeria's sustained democratic experience.

In our view, twenty years is sufficient for the partial and perhaps full manifestation of the implications of Nigeria's democracy. Given this context, this study also contributes to the literature by focusing entirely on applying relevant democratic variables that can represent the nexus between democracy and economic development. Specifically, we apply proxy variables for democracy measurement, the rule of law, government regulations, and corruption control. Unlike the earlier scanty studies on Nigeria's democracy and economic development, this is a significant attempt to quantify the democratic process in a country like Nigeria with timeseries data. That represents another contribution to the body of existing literature.

We arrange the rest of the study as follows: Section 2 examines the contextual definitions of democracy; Section 3 explores economic development in perspective, Section 4 reviews the related literature, Section 5 demonstrates measurement of democracy, Section 6 deals with data analysis, Section 7 analyses the research methodology, Section 8 comprises research method, Section 9 contains the estimation technique procedure, Section 10 shows the discussion of our result, the diagnostic tests and the Granger causality test. Section 11 shows the impulse response function (IRF) in a chart, and Section 12 concludes the study.

\section{Definition of democracy}

The concept of democracy historically emerged from two Greek words: demos, meaning people, and Kratos, implying rule. Schumpeter (1942: 250) contends that democracy '.... is the institutional arrangement for arriving at political decisions in which individuals acquire the power to decide by means of a competitive struggle for the people's vote'. For Dahl (1982:11), democracy is 'a system of elected representative government operated under the rule of law, where the most significant groups in the population participate in the political process and have access to effective representation in the practice of making governmental decisions, that is, of allocation of scarce resources.

Given the assumption in the literature that America is arguably the bastion or model of democracy globally, Abraham Lincoln, the United States' ex-President, defined democracy in 1863 as 'the government of the people, by the people and for the people'. All of the above definitions of democracy possibly represent the conceptual meaning of democracy. The principal deduction from these definitions and others not listed here, is that democracy is a government system with popular participation of the people to elect representatives who govern, serve the population interest, and provide the states with life's necessities. By implication, democracy connotes the competition for power in a free and fair election devoid of intimidation, with the elected public office holders being accountable to the electorates.

\section{Economic Development in Perspective}

The concept of economic development is one of the most widely used terms in economic literature. However, some form of inconsistency exists concerning the meaning of economic development. Economic development is sometimes confused with economic growth, but the two terms are distinct, though inter-related. Contextually, to explain economic development, there is a need to understand economic growth. Previously, prominent development theorists like Todaro and Smith (2012), and Rostow (1960) in his exposition about the stages of economic growth theorised on the concept of economic development. Economic growth is an increase or positive change in output growth in an economy over some period. By the rise in output, we imply an increase in the GDP growth rate. In assessing the output growth, the focus is usually on the per capita output, which denotes the economy's production per head. This per head measurement in an economy shows the economy's health and 
individual wellbeing. Economic development, however, extends beyond economic growth.

Put differently, economic growth appears to be a precondition for economic development. However, economic development involves positive changes in the economic configuration. Economic development is technical knowledge acquisition. It connotes the promotion of intellectual capital, infrastructural development, egalitarian society, and the development of strong institutions. Alain and Elizabeth (2016:31) contend that 'Development is about the enhancement of human wellbeing......'. By implication, economic development is about human welfare advancement and creating policies that make people 'do more, live longer, and have happiness in abundance'. Against this backdrop, international agencies, like the U.N., the World Bank, IMF, and others, have focused more on global development. For instance, in 2000, the U.N. developed Millennium Development Goals, seven capstones of international economic development with a target date of 2015. On the part of the World Bank, several indicators exist to determine development as famously called World Bank Development Indicators. In summary, development is an all-encompassing concept which must be considered from a holistic perspective instead of the narrow view of economic growth.

\section{The Related Literature}

Substantial evidence in the literature demonstrates that on average democracy is the most appealing government system for the widespread participation of the citizen in public office holders' determination and ability to spur economic development (Pel,1999; Somolakae,2007). Over the years, non-democratic states primarily in SubSaharan Africa have observed in amazement the sustained economic development in many of the western democratic countries of the U.S, the UK, Germany, Netherlands, France, and others. The pressure to emulate the development strides in the above-listed countries is one of the primary reasons for many developing countries, including Nigeria, returning to democratic government in 1999 (Omotola,2007). However, Nigeria's democratisation process has opened another dimension into the trajectory of democracy in modern times. In Nigeria's context, there are growing assertions that Nigeria's democratic government has not been entirely responsible for the people's needs and that Nigeria's democratic process, especially the electioneering process, is afflicted with myriads of avoidable drawbacks.

The consensus about democracy and economic development in Africa is a blur. Some political thinkers like Sirowy and Inkels (1991), Bardhan (2002), Prezworski and Lamongi (1993) have probably argued that the relationship between democracy and economic development is negative. Such a view might appear controversial. However, a critical observation of Nigeria's political space revealed two categories of people, the elites and the citizens, as argued by Acemoglu and Robinson (2006:15). They contend in their book titled 'Economic Origins of Dictatorship and Democracy' that elites in the developing states with the democratic government have an enormous influence on the political process against the citizens, potentially breeding inequalities. Practically speaking, in Nigeria, political power through the democratic process rests in the hands of these elites, in contrast to the ethos of democracy in western democracies. That has created many overnight super-wealthy men who control political power over the entire population, given their access to state power. Alapiki (2004:56) opined that 'the wealthiest people in Nigeria are those who have access to state power through political corruption, access to unmerited states contracts, tax waivers, and concessions via import licenses. One harmful effect of such practice is the drain on government revenue. Further, the wealth of the super-rich and politically exposed people sometimes determines the fate of Nigeria's democratic process by the sponsorship of candidates for public office(s) to maintain status-quo. Such conduct potentially leads to political brigandage and mob actions that preclude the rightful candidates from participating in the democratic process, as Gilbert $(2003: 55)$ posited. The aggregate of these factors becomes an impediment to Nigeria's democratic growth.

Given the above, it becomes imperative to determine the implications of democracy on economic development. Democracy is a controversial term in the context of applications. Some scholars have divided democracy into two parts: the western-style democracy and the democracy of the developing states. For instance, the western-style democracy features prominently in the U.S., the UK, Canada, Germany, France, and most advanced countries. However, virtually all the democracies in developing countries, except for a few, follow the second version of democracy riddled with flaws.

Within the last two decades of democracy in Nigeria, several debates have come up in the literature regarding the impact of democratic government on economic development. Using some metrics of growth and economic development as sourced from various agencies, the Nigerian states have not realised the positive effects of democracy. For the poverty rate as a measure of welfare, the rate has been increasing. The prevalence of corruption in Nigeria is still high. The inability of Nigeria's democratic government to find a lasting solution to the insecurity problem ravaging the country's North-East, particularly, has driven out some investors from Nigeria who consider the environment as not too secure for investment. The cumulative effect of the above issues has led to sustained agitations for resource control, restructuring the country into regions, and rising ethnic agitations from various groups like IPOB-Indigenous People of Biafra in the South-east, Oduduwa republic agitators in the South-west, and Middle belt consultative forum among others. The standard position about the 
demands of the ethnic champions is that democracy in Nigeria has promoted the elites' interest over the population, leading to a class struggle for the perceived domination of one ethnic group in the power play of Nigeria above others.

From the preceding, it becomes crucial to determine the implications of democracy on Nigeria's economic development within the first two decades of its sustenance. Relatively few scholars have written in the past concerning the effects of democracy on Nigeria's economic development, especially at its onset (Awojobi et al., 2014; Jamo, 2010). We conceived the idea of this study long ago. However, before starting work on the study, we deliberately took time for the short-run and the long-term impacts of democracy in Nigeria to emerge. In this way, this study represents the first attempt to determine the relationship between democracy and economic development in Nigeria within the first twenty years of uninterrupted democracy. Nigeria has never had such a long period of democracy. The military halted Nigeria's first democratic experience, lasting six years during the first republic. The second republic lasted about five years before the military took the reign of governance. The third republic was aborted mid-way in 1993. Therefore, this study is strategic on many fronts and timely because some political thinkers have argued that democracy is a process and that after twenty years, its manifestation ought to show. We concur with that line of thought-leading us into the measurement of democracy as crafted below.

\section{Measurement of Democracy}

Literature reveals that scholars have attempted to measure democracy. Within the confine of political research on the Nigerian economy, studies like Ajayi and Ojo (2014), Ardo (2000), and Jamo (2010) did not utilise a widely accepted metric to measure democracy in their various studies on democracy and economic development in Nigeria. In this study, we presume that to draw a valid inference in an empirical work about democracy, we should utilise a widely acceptable indicator(s) of democracy. Our crucial measures of democracy in this study are the Polity IV index (2020) of the regime characteristics ranging from 0 to 100 or -10 to +10 , and the Worldwide Governance Indicators by Daniel Kaufmann and Aart Kraay (2020). The advantages of the two sources of democracy metrics in this study include:

[a] Evidence abounds in the literature that democracy, as practised in the developed economies, differs from the democratic procedures of developing countries like Nigeria. Such disparity in democratisation has led to two dichotomies of democracy in the literature; first, the western model of democracy otherwise known as the ideal form of democracy which promotes economic development in first world countries. However, many developing countries like Nigeria, Togo, Angola, and Venezuela, practice pseudo-democracy-probably defective in its implementation and approach. In this sense, democracy is likely not to have uniform effects across all the countries, or perhaps in all the newly democratise developing countries. As such, the measurement of democracy should reflect both the ideal form of democracy and the pseudo-democracy. The Polity IV index of democracy and the Worldwide Governance Indicators significantly demonstrate countries' transition process from pseudodemocracy to ideal democracy. Both metrics are in the range of numbers indicating the probability of coverage of all the democratisation processes in most states. For instance, for the Polity IV index of regime characteristics (2020), 100 or +10 represents full democracy, whilst 0 or -10 implies an autocratic regime. Still, the various governance system exists between the lower bound of 0 and higher bound of 100. For the Worldwide Governance Indicators, it ranges from -2.5 as the lower bound to +2.5 as the higher bound reflecting varying government degrees. Scholars have used these indicators as exemplified in Barro (1998). Interestingly, we can explore the trajectory of democracy in Nigeria within the last two decades in the two-democracy metrics context.

[b] For the political literature assumption that the control of corruption under the democratic government is better than the military regime given the accountability of a democratic government to the population, there is a need to search for a variable to denote corruption control under the democratic government. In a sense, corruption control is controversial because of the concept's subjectivity and the perceived shortcomings associated with its measurement. Empirical evidence suggests that many of the metrics of corruption are poorly and controversially measured. Nonetheless, the consensus in the literature is that corruption impedes economic development. In Nigeria's context, the corruption problem is one of the significant impediments to economic development. The recognition of this challenge is traceable to establishing the two domestic anti-corruption agencies in Nigeria, notably, the Economic and Financial Crime Commission (EFCC) in 1999 and the Independent Corrupt Practices Commission in 2000. One widely acceptable measurement of corruption is the perception index of corruption from Transparency International. In Nigeria's context, there is an allegation of bias about the country's ranking by Transparency International. Therefore, drawing from the literature's evidence, we augment the application of variables for democracy in this study with quality of corruption control from the Worldwide Governance Indicators, free from the subjective opinion of Nigerians about its corruption index. The Worldwide Governance Indicators are a unique project on governance partly funded by the World Bank. Such a metric of corruption control is justified as a measurement of the democratic process in Nigeria. 


\section{Data Analysis}

To assess the impact of democracy on economic development in Nigeria, this study applies annual time-series data for 20 years of sustained democratic government in Nigeria between 1999 and 2019. We utilize the per capita real GDP growth rate sourced from World Development Indicators (2020) to proxy economic development. We apply three democracy indicators: Polity IV index of democracy from the Freedom House (2020), we source for quality of government regulations, the rule of law index, and quality of corruption control from the Worldwide Governance Indicators (2020).

\section{Methodology and Estimation Techniques}

In this part of the study, we develop a model of economic development for Nigeria. We aim to determine if democracy has driven Nigeria's economic development within the past twenty years of sustained democratic government. This study follows the strand of the political economy literature of Acemoglu et al. (2019) and Garring et al. (2005:323) seeking to link economic growth and development with the democratisation process of economies. Also, our discussion of the linkage between democracy and economic development is timely, given that twenty years is good enough for perceived long-run implications of democracy on economic development to begin to emerge. We estimate the following regression equation:

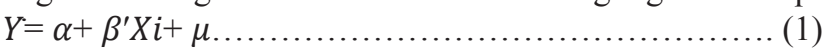

In equation 1 above, $Y$ is the proxy variable for the annual rate of economic development in Nigeria. The intercept is $\alpha$ and our $\beta^{\prime}$ captures the vector of variables that affect economic development in Nigeria, whilst $\mu$ is the error term. The choice of explanatory variables for our model equation, as specified below, follows the assumptions about economic development in Acemoglu et al. (2005, 2019), Barro (1998), Gerring et al. (2005), Przewprski and Lamongi (2007), Sirowy and Linkels (1991) and others about the formulation of a model of economic development with the democratic process. The specific model for this study is given as:

$\mathrm{PGDP}=\mathrm{f}(\mathrm{DEMO}, \mathrm{REGO}, \mathrm{QCOR})$

PGDP is the per capita real GDP growth rate of Nigeria that proxy Nigeria's economic development between 1999 and 2019. DEMO is the democracy metric for Nigeria, denoting the democratic governance ranking in Nigeria within our study period. REGO is a composite variable derived from the interaction of government regulations and the rule of law in Nigeria to proxy the institutionalised democratic rule of law in the country. QCOR is the quality of corruption control in Nigeria within the period of our study. The functional form of our econometric model is in level-level:

$P G D P t=\propto 0+\beta 1 D E M O t+\beta 2 R E G O t+\beta 3 Q C O R t+\mu$

We briefly justify the inclusion and utilization of our explanatory variables below: There are variants of democracy indicators and measurements from various sources like the Polity IV index, Worldwide Governance Indicators, and the CESifo group, among others. In this study, we utilize the democracy metrics from the Polity IV index of regime characteristics given its advantage over some other democracy qualities. The trajectory of the Nigerian political space revolves around periods of military rule and democratic government. Therefore, the measurement indicators for Nigerian democracy should explore the trends in the transition from military to pseudo-democracy and democracy. Further, arguments have been put forward that the Nigerian version of democracy is still in infancy, given its associated challenges. Therefore, the Polity IV index of democracy, ranging from -10 to +10 or 0 to 100 points representing a varying degree of democratic governance, better serves our purpose of measurement of Nigeria's democracy. One of the known characteristics of a democratic government is the enshrinement of the rule of law's principle. Some scholars have argued that the primary difference between an autocratic regime and a democratic government is the absence of the rule of law under an authoritarian regime. We introduce a composite explanatory variable to determine the impact of the rule of law in Nigeria's democratic government in the model. Corruption is one of the many challenges confronting economic development in Nigeria. Nigeria and the international community assumed that once democracy was established in 1999, the country's corruption problem would be better addressed under a democratic government. Given that position, we introduce an explanatory variable for Nigeria's corruption control under the democratic government.

\section{Research Method}

In this study, we apply an econometric method of the Johannsen Cointegration VAR model developed by Johansen (1988) and Juselius $(1990,1992)$. One advantage of the vector autoregressive model is that it permits each of the variables in the equation's system to explain its effect on itself. Further, the system variables explain corresponding impacts on the other variable in the regression equation without imposing a theoretical structure on the estimates. It also permits the application of forecast experiments with the IRF or the variance decomposition. The primary interest of the study is to determine the impacts of democracy on economic development. Therefore, we use three explanatory variables to denote democracy metrics, as illustrated in equation (3). 


\section{Estimation Procedure}

This study's estimation procedure begins with determining an optimal lag structure, as shown in Table 7 (See appendices), indicating the two lag structures use. The next important task is to perform the unit root test on the time-series macro-variables in our model. The unit root test is useful for determining the stationary of our variables, by implication to determine if our variables show some features like mean reversion and finite variance (Babatunde and Adefabi, 2005). We use the Augmented Dickey-Fuller unit root test to determine our variables' stationary conditions. For variables to be worthy of the VAR autoregressive method, they must not be stationary at level. However, when converted into the first difference, it must be stationary: integration of order one -I (1)

In the next order, we perform the Johansen cointegration test to determine if there is a long-run association among the variables. If the outcome of the Cointegration test indicates a long-run association among the variables, we perform the Vector Error Correction Model (VECM); otherwise, we follow the Vector autoregressive (VAR) model's path or SVAR. Our cointegration test performed for model variables specified above indicates the existence of a long-run association among our variables of interest: $P G D P, D E M O, R E G O$, and $Q C O R$. To determine our variable's response to each of the impulse variables, we carried out the IRF, the output of which is presented in Figure 1.

\section{Empirical Analysis and Discussion of Results \\ 10.1 Stationary Test}

We use the Augmented Dickey-Fuller (ADF) approach to determine our variables' order of integration level. Table 1 below presents the outcome of the unit root tests with the ADF. Table 1 illustrates the dynamics of the variables in their levels and first difference form. The null hypothesis for the ADF at a 5\% level of significance is that our variable has a unit root or not stationary. The alternative hypothesis is that our variable does not have a unit root or is stationary.

Table 1: Unit Root Tests for Stationarity with Augmented Dickey-Fuller in levels and first difference

\begin{tabular}{|l|l|l|l|l|l|l|}
\hline \multirow{2}{*}{ Series } & \multicolumn{3}{|l|}{ Augmented Dickey-Fuller at Level } & \multicolumn{3}{l|}{ Augmented Dickey-Fuller at first difference } \\
\cline { 2 - 7 } & Test Statistics & $5 \%$ Critical Value & Outcome & Test Statistics & 5\% Critical Value & Outcome \\
\hline PGDP & -2.530958 & -3.020686 & $\mathrm{I}(0)$ & -6.618872 & -3.052169 & $\mathrm{I}(1)$ \\
\hline DEMO & -0.781283 & -3.020686 & $\mathrm{I}(0)$ & -4.812757 & -3.029970 & $\mathrm{I}(1)$ \\
\hline REGO & -2.110910 & -3.052169 & $\mathrm{I}(0)$ & -3.892375 & -3.065585 & $\mathrm{I}(1)$ \\
\hline QCOR & -2.450483 & -3.052169 & $\mathrm{I}(0)$ & -3.729322 & -3.065585 & $\mathrm{I}(1)$ \\
\hline Source: Author's Computations using Eviews 10. \\
\hline
\end{tabular}

From Table 1 above, all our variables: $P G D P, D E M O, Q C O R$, and $R E G O$ have a unit root, by implication they are not stationary at the level since each of the respective tests statistics values for all the variables are less than the critical values. However, in the conversion to the first difference, each of the test statistics, as indicated in Table 1, is greater than the critical values, indicating integration of order one, I (1). From the analysis of the stationary test above, we can conclude that our variables of interest have a unit root, therefore, we undertake the cointegration test.

\subsection{Cointegration Test}

Table 2 below presents the results of the Johansen cointegration test for this study. The decision rule is that if the trace statistics value is greater than the $5 \%$ critical value, we can conclude that there is cointegration among the tested variables; otherwise, we conclude that there is no cointegration among the variables.

\begin{tabular}{|l|l|l|l|l|l|}
\hline \multicolumn{6}{|l|}{ Table 2: Johansen Co-integration Test Result Showing Number of Cointegrating Vectors } \\
\hline $\begin{array}{l}\text { Hypothesized Number of Eigenvalue } \\
\text { Cointegration }\end{array}$ & $\begin{array}{l}\text { Trace } \\
\text { Statistics }\end{array}$ & $\begin{array}{l}5 \% \text { Critical } \\
\text { Value }\end{array}$ & $\begin{array}{l}\text { Probability } \\
\text { Value }\end{array}$ & Decision \\
\hline None* & 0.940044 & 66.33206 & 47.85613 & 0.004 & Cointegrating \\
\hline At most 1 & 0.570580 & 21.30563 & 29.79707 & 0.3389 & $\begin{array}{l}\text { Not } \\
\text { Cointegrating }\end{array}$ \\
\hline At most 2 & 0.324387 & 7.780532 & 15.49471 & 0.4892 & $\begin{array}{l}\text { Not } \\
\text { Cointegrating }\end{array}$ \\
\hline At most 3 & 0.089852 & 1.506371 & 3.841466 & 0.2197 & $\begin{array}{l}\text { Not } \\
\text { Cointegrating }\end{array}$ \\
\hline Source: Author's Computation using Eviews 10.
\end{tabular}

The trace statistics of 66.33206 , as shown in Table 2 above, are greater than the critical $5 \%$ value of 47.85613. Therefore, we can conclude that there is one cointegration among the variables being tested. This outcome's interpretation is that there is a long-run relationship among $P G D P, D E M O, Q C O R$, and $R E G O$. More 
specifically, assumptions hold that all our four variables are not likely to move far apart in the long-run. With the outcome of the Johansen cointegration test, we can perform VECM since there is evidence of a long-run relationship among our variables of interest.

\subsection{Vector Error Correction Model Output}

We illustrate the output of our VECM in Tables 3 and 4. The first table shows the Johansen normalisation cointegration vector. Interpretatively, it represents the long-run equilibrium solution of our regression equation model. In Table 4, the vector error correction estimates, which is the short-run -OLS regression estimates for our model.

\begin{tabular}{|l|l|}
\hline \multicolumn{2}{|l|}{ Table 3: Johansen Normalization Cointegration Vector or Long Run Equilibrium Solution } \\
\hline Co-integration Equation & Long Run Solution \\
\hline PGDP & 1.00 \\
\hline DEMO & 1.188874 \\
& $(23.50)$ \\
\hline REGO & -6.69049 \\
& $(-19.12)$ \\
\hline QCOR & -7.005771 \\
& $(-7.60)$ \\
\hline Constant & -9.532909 \\
\hline Note: t statistics in parenthesis. The signs of the coefficients would become opposite in the long -run \\
interpretation. \\
\hline$E_{C-1}=\left[1.00 P G D P_{t-1}-6.69049 R E G O_{t-1}-7.005771 Q C O R_{t-1}+1.188874 D E M O_{t-1}\right]$ \\
\hline Source: Author's Computation using Stata/ I/C 15.1. \\
\hline
\end{tabular}

From Table 3 above - the Johansen Normalization Cointegration, we can observe a long-run positive relationship among the quality of regulation and the rule of law, control of corruption, and economic development in Nigeria. However, contrary to our prior expectation, there is a negative long-run relationship between democracy and economic development in Nigeria. The estimated coefficients are significant at the 5\% level. This finding aligns with the conclusions of scholars like Bardhan (2002), Gerring et al. (2005), Sirowy and Linkels (1991), and Przeworski and Lamongi (2007) about the potential inverse relationship between democracy and economic growth. Fundamentally speaking, Nigeria's democratic operations since 1999 have continued to evoke stringent investigations about the lack of clarity of direction, non or low existent of the dividend of democracy, electoral malpractices, voter's apathy; the combination of those factors has led to weak democratic institutions. Therefore, our finding of an inverse association between democracy and economic development in Nigeria is plausible. Given the divergent position between the western-style democracy and the developing state's model of democracy, the democratic experience of the Nigerian state appears to be parallel to the ideals of democracy as enshrined in the political economy literature.

\begin{tabular}{|c|c|c|c|c|}
\hline Equation & D(PGDP) & D(REGO) & $\mathrm{D}(\mathrm{QCOR})$ & D(DEMO) \\
\hline CointEq1 & $\begin{array}{l}-0.2334917 \\
(-0.41)\end{array}$ & $\begin{array}{l}0.2071441 * \\
(3.60)\end{array}$ & $\begin{array}{l}-0.039988 \\
(-1.22)\end{array}$ & $\begin{array}{l}0.4214963 \\
(1.29)\end{array}$ \\
\hline $\mathrm{D}$ (PGDP) [-1] & $\begin{array}{l}-0.1249622 \\
(-0.46)\end{array}$ & $\begin{array}{l}-0.0824639 * \\
(-3.04)\end{array}$ & $\begin{array}{l}0.0148667 \\
(0.97)\end{array}$ & $\begin{array}{l}-0.1520028 \\
(-0.99)\end{array}$ \\
\hline $\mathrm{D}(\mathrm{DEMO})[-1]$ & $\begin{array}{l}-1.143179 \\
(-1.36)\end{array}$ & $\begin{array}{l}-0.2506664^{*} \\
(-2.97)\end{array}$ & $\begin{array}{l}0.0510384 \\
(1.06)\end{array}$ & $\begin{array}{l}-0.453988 \\
(-0.95)\end{array}$ \\
\hline $\mathrm{D}(\mathrm{REGO})[-1]$ & $\begin{array}{l}0.0188401 \\
(0.01)\end{array}$ & $\begin{array}{l}0.2729327 \\
(1.32)\end{array}$ & $\begin{array}{l}-0.0513707 \\
(-0.33)\end{array}$ & $\begin{array}{l}1.532238 \\
(0.99)\end{array}$ \\
\hline $\mathrm{D}(\mathrm{QCOR})[-1]$ & $\begin{array}{l}2.885455 \\
(0.33)\end{array}$ & $\begin{array}{l}1.300081 \\
(1.50)\end{array}$ & $\begin{array}{l}-0.33747 \\
(-0.68)\end{array}$ & $\begin{array}{l}2.279424 \\
(0.46)\end{array}$ \\
\hline $\mathrm{C}$ & $\begin{array}{l}-0.0766011 \\
(-0.12)\end{array}$ & $\begin{array}{l}-0.1733806 \\
(-2.75)\end{array}$ & $\begin{array}{l}0.0425291 \\
(1.19)\end{array}$ & $\begin{array}{l}0.0468086 \\
(0.13)\end{array}$ \\
\hline R-Squared & 0.4058 & 0.6170 & 0.1759 & 0.2427 \\
\hline F Statistics & 0.6830471 & 16.11081 & 2.134945 & 3.204974 \\
\hline Likelihood & 0.3368 & 0.0132 & 0.9069 & 0.7827 \\
\hline \multicolumn{5}{|c|}{$\triangle^{P G D P_{t}}=-0.077-0.125 \Delta^{P G D P_{t-1}}+0.019 \Delta^{R E G O_{t-1}}+2.886 \Delta Q C O R_{t-1}-1.143 \Delta^{D E M O_{t-1}}-0.234 E C T_{t-1}$} \\
\hline \multicolumn{5}{|c|}{ Note: t- statistics in parentheses. } \\
\hline \multicolumn{5}{|c|}{ Source: Author's Computation using Stata / I/C 15.1. } \\
\hline
\end{tabular}


Democracy indicator, as seen in Table 4, illustrates an adverse and statistically insignificant effect of -1.143 in the estimated economic development proxy equation. Interpretatively, one lag period of democracy in Nigeria has a negative but insignificant effect on Nigeria's economic development. Democracy, as practised in Nigeria, has come under empirical attacks given that it probably negates the acceptable standard of democratic governance. The possible violation of the rule of law appears to be present in the Nigerian polity. For example, the allegation of killings of the \#ENDSARS protesters in Lekki, Lagos Nigeria in 2020 has led to international condemnation of the Nigerian government for the invitation of the military to quell an organised protest by unarmed youths demonstrating against police brutalities and misgovernance in Nigeria.

Furthermore, the Nigerian government has taken steps in recent times to curtail freedom of speech through the hate speech penal code or law and other non-democratic actions. The electoral process in Nigeria is prone to challenges like most developing states across the world. The likely skew electoral process probably facilitates the wrong candidates to get into elective positions and serve some vested interest. The political office holders in Nigeria perhaps assume that holding public offices is an automatic avenue to become wealthy. The cost of governance in Nigeria is also another impediment to the realisation of the dividend of democracy. In the word of Alapiki (2004), the wealthiest people in Nigeria are those who have access to political or public offices. The weak political institutions in Nigeria, as pointed out by Acemoglu et al. (2012), have further complicated the democratisation trajectory of Nigeria. From all of the listed conditions, the likelihood exists that democracy has not contributed meaningfully to the Nigerian economic development between 1999 and 2019. However, democracy, if well managed, can promote economic development like the world's advanced economies.

Table 4 shows that the adjustment term (-0.234) shows no evidence of statistical significance at a $5 \%$ level of significance, suggesting that the previous year's errors or perhaps the deviation from the long-run equilibrium are not corrected for within the current year at a convergence speed of 0.234 percentage point. For the quality of regulation and the rule of law, we found evidence of statistically significant yearly adjustment, as illustrated in Table 4, with an estimated $0.207 *$.

The quality of regulations and the rule of law in Nigeria had a direct but statistically insignificant effect of 0.019 in the estimated economic development proxy regression equation. Specifically, the one-period lag of quality of regulations and the rule of law in Nigeria, although positive, does not have a significant implication on the Nigerian economic development within our study period.

The control of corruption in Nigeria exact positive but a statistically insignificant effect of 2.886 in the estimated economic development proxy regression equation in Table 4. One lag period of control of corruption in Nigeria does not have a significant impact on economic development. The deduction from this finding is that the fight against corruption in Nigeria is plausible, given that corruption impedes economic growth. However, the outcome of such a corruption fight since 1999 in Nigeria, as observed from our finding, is statistically insignificant. Evidence in Nigeria shows that the agencies responsible for the fight against corruption are sometimes enmeshed in corruption. For instance, the substantive chairman of the Economic and Financial Crime Commission in Nigeria (EFCC), Mr. Ibrahim Magu was suspended by the President in 2020 primarily for corruption allegations and was later removed from office in a controversial manner. Such development sometimes cast aspersions on the activities of the anti-corruption watchdog.

Besides, there are allegations in Nigeria that the ruling party probably manipulate the anti-corruption agencies to settle political scores, especially with opposition. The aggregate of all of these factors might have played roles in the insignificant positive effects of corruption control on economic development in Nigeria.

\subsection{Diagnostic Tests}

Given our Johansen cointegration output, as discussed above, we follow up with the required diagnostic tests, namely the normality test and the autocorrelation test.

\begin{tabular}{|l|l|}
\hline \multicolumn{2}{|l|}{ Table 5: Diagnostic Tests } \\
\hline Diagnostic Tests & Chi-Square Probability Value \\
\hline Jarque-Bera Normality test (ALL) & 0.9775 \\
\hline LM Test of Autocorrelation \\
\hline Lag 1 & 0.87279 \\
\hline Lag 2 & 0.89639 \\
\hline Source: Author's Computation using Stata /IC 15.1
\end{tabular}

From Table 5, we use the Jarque-Bera Normality test to determine if our variables' residuals have a normal distribution. The null hypothesis, at a $5 \%$ level of significance, is that the residuals of variables have normal distribution whilst the alternative says otherwise. Our probability value with Chi-square distribution is 0.9775clearly above the 5\% level thresholds. We can safely conclude that our variables have a normal distribution. For an autocorrelation test, we utilise the L.M. test of autocorrelation.

In Table 5, focusing on lag 2 , we can observe that no autocorrelation's null hypothesis cannot be rejected 
since 0.89639 is above the $5 \%$ critical value. The two diagnostics tests imply that our model is well specified, and by extension, the results are tenable.

\subsection{Granger Causality Test}

Table 6 portrays the Wald tests for our Granger causality tests. We discuss each of the outcomes of the Granger causality tests below.

\begin{tabular}{|l|l|l|l|l|l|}
\hline \multicolumn{7}{|l|}{ Table 6: Granger Causality Test Results } \\
\hline Dependent Variables & \multicolumn{7}{l|}{ Chi-Square Statistics P-Values } & Joint Causality \\
\hline & PGDP & REGO & QCOR & DEMO & J \\
\hline PGDP & - & 0.9945 & 0.7396 & 0.1754 & 0.5844 \\
\hline REGO & $0.0023^{*}$ & - & 0.1348 & $0.0030^{*}$ & $0.0061^{*}$ \\
\hline QCOR & 0.3337 & 0.7402 & - & 0.2874 & 0.7268 \\
\hline DEMO & 0.3215 & 0.3213 & 0.6433 & - & 0.7634 \\
\hline * Denotes 5\% level of significance of Chi-Square Probability Values. & & \\
\hline Source: Author's Computation using Stata / I/C 15.1 \\
\hline
\end{tabular}

From the Granger test result, we can observe that the quality of regulation and the rule of law did not Granger-cause economic development in Nigeria since the probability value of 0.9945 is above the $5 \%$ critical value thresholds within the period of our study. The quality of corruption control did not also Granger-cause economic development as observe in Table 6 because the Chi-square probability value of 0.7396 is above 5\% critical value. Last, the democracy indicator with a Chi-square probability value of 0.1754 did not Granger-cause economic development between 1999 and 2019. Jointly, all the democratic metrics used in Table 6 did not Granger-cause economic development during our study period. In a way, the Granger causality tests further reinforce our observations and findings with the VECM.

\section{Impulse Response Function}

We explain the changing properties of our VECM model with the IRF application, as captured below in Figure 1. Figure 1 demonstrates the response of our dependent variable, economic development proxy to various shocks. Using 10 years of the future forecast, we observe that the reaction of DEMO to one standard deviation shock in $P G D P$ is an increasing negative sign from the first period to the tenth period, which underscores our findings of the negative relationship between the Nigerian democracy and economic development during our study period.

Further, $Q C O R$ follows the same pattern with the DEMO in its impulse response. However, REGO is positive in the first period with an increasing positive throughout the short-run, (period 5), it slightly declines in period 6 but maintains a positive outlook till period 10. Our IRF implies that our two explanatory variables' reaction, $D E M O$, and $Q C O R$, to a standard deviation shock in $P G D P$, are negative in the short-run and the longrun.

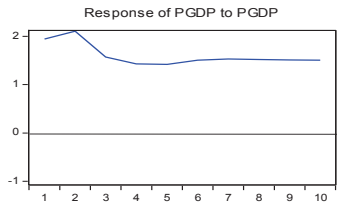

Response of DEMO to PGDP

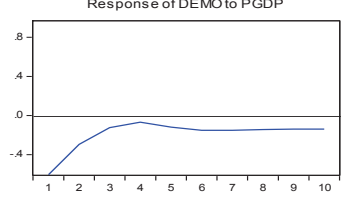

Response of QCOR to PGDP
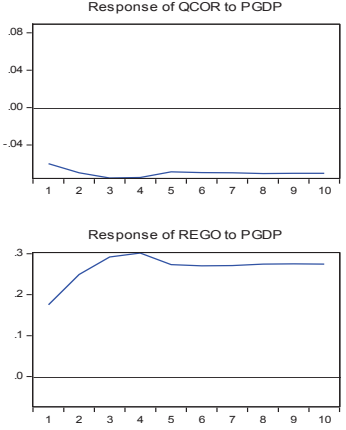

Response to Cholesky One S.D. (d.f. adjusted) Innov ations

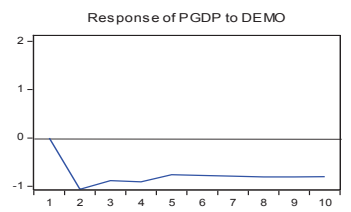

Response of DEMO to DEMO

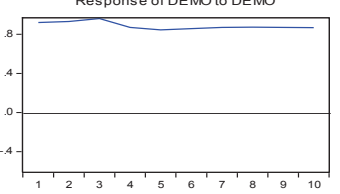

Response of QCOR to DEMO

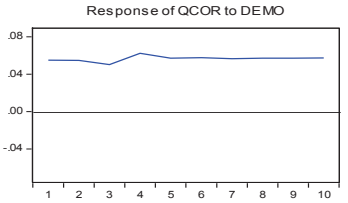

Response of REGO to DEMO

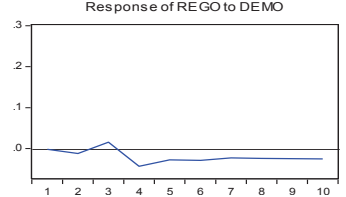

Response of PGDP to QCOR

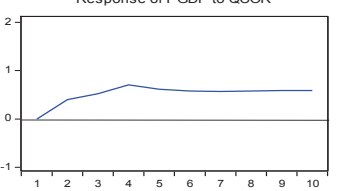

Response of DEMO to QCOR

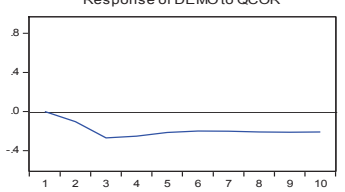

Response of QCOR to QCOR

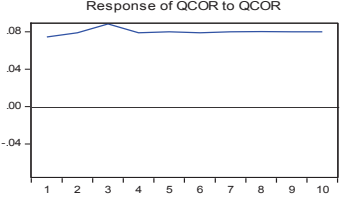

Response of REGO to QCOR

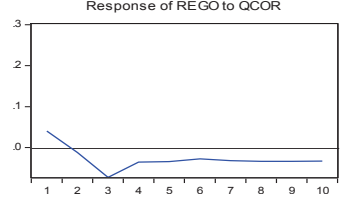

Response of PGDP to REGO

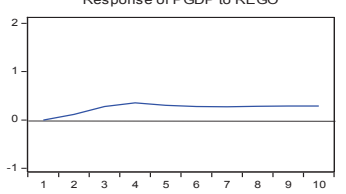

Response of DEMO to REGO

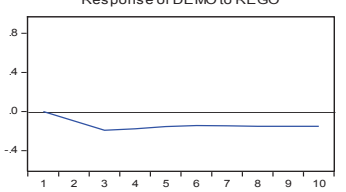

Response of QCOR to REGO

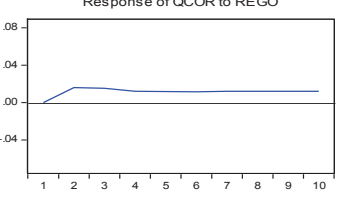

Response of REGO to REGO

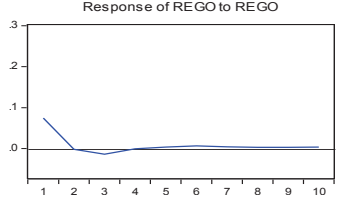




\section{Conclusions}

This study investigates the relationship between democracy and economic development in Nigeria. This study's crucial findings are as follows: first, evidence in the Johannsen cointegration shows a long-run equilibrium relationship among our variables of interest in the model. Specifically, the result of our Johansen cointegration indicates that Nigeria's economic development and democracy likely move together in the long-run. However, the results demonstrate that democracy had a negative relationship with the Nigerian economic development during our study (1999 -2019), aligning with Madu et al.'s (2015) position.

Furthermore, we found no evidence of causality between democracy and economic development during the same period. The applied IRF also suggests a possible negative economic development response to democracy. Nigeria arguably runs one of the most expensive democratic governments in Sub-Saharan Africa, with an overbloated wage bill for the political office holders to the detriment of the state's core developmental objectives. Besides, the population's lack of trust in the democratic process has negatively contributed to the voter's apathy, helping the privileged few in Nigeria to perpetuate their political domination on the entire country.

This study further identifies evidence of a long-run equilibrium relationship among the control of corruption variables, quality of regulations with the rule of law, and economic development. Unlike the identified association between democracy and economic development in Nigeria, an inverse, we observe a positive relationship between regulatory quality (with the rule of law) and economic development. However, we found no evidence of causality among the variables during our study period. In a way, the rule of law is one of the democratic sub-structures that societies should implement to guarantee a vital democratic institution. An improvement in the Nigerian government's commitment to the fight against corruption would expand the country's political space. The promotion of the rule of law is also crucial for the democratisation process.

We identify a positive (but statistically insignificant in the short run) association between the control of corruption in Nigeria and economic development. Our result possibly underpins the presumption about defects in the anti-corruption campaign of the Nigerian government in the literature. For example, there are allegations of discriminatory conduct by the anti-corruption agencies of Nigeria in pursuing assignments. There are shreds of evidence that if the agencies are free from political interference and control, they can perform better.

From the policy perspective, Nigeria's democratic space should be strengthened more. Political participation is very crucial to the democratization process. Observable evidence suggests that very few percentages of Nigerians participate in the electoral process. The monetization of Nigeria's electoral system is probably to disadvantage many of the interested Nigerians in the democratic process. Vital political reform should be put in place to promote voters' education and constitutionalism.

Moreover, a review of the wages and emoluments of political officeholders in Nigeria is essential. The situation in which ex-governors are entitled to robust retirement packages in cash and kind whilst serving as sitting senators in the National assembly or as ministers or Heads of government agencies, and collecting salary and allowances for such position does not sound well for the fiscal health of the country. Such financial misadventure is tantamount to leakages and unjustifiable withdrawal in the economy. Perhaps, there should be an introduction of civic responsibilities courses in the Nigerian school system and political history pattern after the U.S. history and constitutionalism in the school system. Such political literacy education could advance the Nigerian youths' knowledge of promoting democratic government through conscious political participation. Substantial evidence suggests that democracy promotes development; therefore, the Nigerian state can benefit from the dividend of democracy with robust democratic strategies.

Finally, for Nigeria's democratic space to develop fully, the Nigerian population should avoid anti-growth maladies. Such vices include ethnicity, sectionalism, and illiteracy or deliberate efforts to restrict education in some parts of Nigeria. To a large extent, the aggregate of these four factors is the most potent electoral manipulation tool of some politicians in Nigeria. As such, the Nigerian population should look beyond these barriers to realize democratic dividends and develop a vital democratic institution.

\section{References}

1. Acemoglu, D; Robinson, J. A; Suresh, N; Pascual, R. (2019). Democracy Does Cause Growth. Journal of Political Economy, 127:1, pp 47-100.

2. Acemoglu, D; Robinson, J. A; and Simon, J. (2005). Institutions as a Fundamental Cause of Long-Run Growth. Handbook of Economic Growth 1A: 386-472.

3. Ajayi, A., and Ojo, E. (2014). Democracy in Nigeria: Practice, Problems and Prospects. Developing Country Studies, 4, 107-125.

4. Ardo, U. (2000). Democracy and Africa: A Historical Overview. In the Journal of Human Rights, Democracy and Good Governance. Ahmadu Bello University, Zaria.

5. Alain, De Janvry and Elisabeth, Sadoulet. (2016). Development Economics. New York: Routledge, https://doi.org/10.4324/9781315715520.

6. Alapiki, H. E. (2004). The Nigerian Political Process. Uyo; Abigab Associates Ltd. 
7. Alapiki, H.E. (2005). Politics and Governance in Nigeria. Nigeria: Shapee Publishers.

8. Awojobi, Oladayo; Ayakpat, Joyce; Adisa, Oladimeji David. (2014). 15 Years of Uninterrupted Democracy in Nigeria. What is the Correlation between Democracy and Development? International Journal of Economics, Commerce and Management, Vol. 2, Issue 8.

9. Babatunde, M.A. and Adefabi, R.A (2005). Long Run Relationship between Education and Economic Growth in Nigeria: Evidence from the Johansen's Cointegration Approach. Paper presented at the Regional Conference on Education in West Africa: Constraints and Opportunities, Senegal.

10. Bardhan, Pranab. (2002). Decentralisation of Governance and Development. Journal of Economic Perspectives, 16 (4): 185-205.DOI: 10.1257/089533002320951037.

11. Barro, R. J. (1998). Determinants of Economic Growth: A Cross-Country Empirical Study, MIT Press Books, The MIT Press, edition 1.

12. Daniel, Kaufmann and Aart, Kraay. (2020). The worldwide governance indicators: methodology and analytical issues. Policy Research Working Papers.

13. Gerring, J., Bond, P., Barndt, W., and Moreno, C. (2005). Democracy and Economic Growth: A Historical Perspective. World Politics, 57(3), 323-364. doi:10.1353/wp.2006.0002.

14. Gilbert, L.D. (2003). Elements of Political Science. Port Harcourt: Minson Publishers.

15. Jamo, I. A. (2009). Democracy and Development in Nigeria: Issues and Challenges. Proceedings of the 2010 International Conference on the Global Financial Crises and Africa "s Quest for Development. Faculty of Administration, Ahmadu Bello University Zaria.

16. Jamo, I. A. (2013). Democracy and Development in Nigeria: Is There a Link? Arabian Journal of Business and Management Review (OMAN Chapter) Vol. 3, No.3; Oct. 2013. 85-94.

Johansen, S. (1988). Statistical Analysis of Cointegration Vectors. Journal of Economic Dynamics and Control, $12,231-254$.

17. Johansen, S. and Juselius, K. (1990). Maximum Likelihood Estimation and Inference on Cointegration with Applications to Demand for Money. Oxford Bulletin of Economics and Statistics 52, 169-210.

18. Lake, D. A. and Baum, M. A. (2001). The Invisible Hand of Democracy: Political Control and the Provision of Public Services, Comparative Political Studies, 34(6), pp. 587-621. DOI: 10.1177/0010414001034006001

19. Madu, A.Y., Yusof, R., \& Suyatno. (2015). Democracy and Rural Development in Nigeria's Fourth Republic: Challenges and Prospect. Mediterranean journal of social sciences, 6, 445.

20. Olson, Mancur. (1993). Dictatorship, Democracy, and Development. The American Political Science Review, Vol. 87, No. 3 (Sep., 1993), pp. 567-576.

21. Olu-Adeyemi, L. (2012). The Challenges of Democratic Governance in Nigeria. International Journal of Business and Social Science Vol. 3 No. 5; March 2012. 167-171.

22. Omotola, J. S. (2007). Democratisation, Good Governance and Development in Africa: The Nigerian

Experience. Journal of Sustainable Development in Africa (Volume 9, No.4, 2007) ISSN: 1520-5509. Fayetteville State University, Fayetteville, North Carolina. 247-274.

23. Omotola, Shola. (2009). Garrison' Democracy in Nigeria: The 2007 General Elections and the Prospects of Democratic Consolidation. Commonwealth \& Comparative Politics - 47. 194-220.

24. Pel, M. (1999). Economic Institutions, Democracy and Development, A Paper presented at the Conference on Democracy and Development, World Bank Conference, Korea. February 26-27, 1999.

25. Przeworski, Adam, and Fernando Limongi. (1993). Political Regimes and Economic Growth. Journal of Economic Perspectives, 7 (3): 51-69.DOI: 10.1257/jep.7.3.51.

26. Ross, L. M. (2001). Does Oil Hinder Democracy? World Politics 53:3, Cambridge University Press.

27. Ross, L. M. (2006). Is Democracy Good for the Poor? Journal of Political Science, Vol.50, No 4, pp 860-874.

28. Rostow, W. (1960). The Stages of Economic Growth: A Non-Communist Manifesto (3rd ed.). Cambridge: Cambridge University Press. doi:10.1017/CBO9780511625824. Reprinted in 1991.

29. Somolakae, G. (2007). The Democracy and Development Nexus: Exploring the Linkages. In International Conference on Sustaining Africa's Democratic Momentum Paper. Sandton Convention Centre, Johannesburg, S.A.

30. Sirowy, L. and Inkeles, A. (1990). The Effects of Democracy on Economic Growth and Inequality: A review. St Comp Int Dev 25, 126-157. https://doi.org/10.1007/BF02716908.

31. Todaro, M.P. and Smith, S.C. (2012). Economic Development (11th ed.). Boston: Pearson Addison Wesley. 
Appendices

Table 7: Lag Selection Criteria Result

\begin{tabular}{|l|l|l|l|l|}
\hline & \multicolumn{3}{|c|}{ Criterion } & SC \\
\cline { 2 - 5 } & FPE & AIC & 2 & HQC \\
\hline Lag & 2 & 2 & 2 & 2 \\
\hline \multicolumn{5}{|l|}{ Source: Author's Computation. }
\end{tabular}

FPE=Final Prediction Error

$\mathrm{AIC}=$ Akaike Information Criterion

$\mathrm{SC}=$ Schwartz Criterion

$\mathrm{HQC}=$ Hannan-Quinn Criterion 